\title{
Survey Secara Online Menggunakan Google Form Pada Posyandu Seruni
}

\author{
Agus Junaidi ${ }^{1}$, Rachmat Hidayat ${ }^{2}$, Wahyudin ${ }^{3}$, Ahmad Yani $^{4}$, Khairunnisa Zakaria $^{5}$ \\ 1,2,3,4,5 Universitas Bina Sarana Informatika \\ J1.Kramat Raya No.98, Senen, Jakarta Pusat, Indonesia \\ e-mail: ${ }^{1}$ agus.asj@bsi.ac.id, ${ }^{2}$ rachmat.rch@bsi.ac.id, ${ }^{3}$ wahyudin.whd@bsi.ac.id, \\ ${ }^{4}$ ahmad.amy@bsi.ac.id, ${ }^{5}$ khairunnisazp13@gmail.com
}

\begin{abstract}
Abstrak
Dalam kondisi pandemi seperti saat ini, banyak kegiatan yang tidak dapat dilakukan secara normal dengan bertemu dan berkumpul yang melibatkan banyak orang dalam sebuah acara. Hal ini dapat menjadi masalah jika harus melakukan pengumpulan data untuk keperluan penelitian maupun keperluan pribadi lainnya. Walaupun dimasa pandemi tetapi kegiatan untuk Ibu-ibu Posyandu juga harus tetap berjalan dengan menerapkan protokol kesehatan yang ketat demi menjaga penularan virus corona. Untuk mengurangi kegiatan berkumpul yang tidak bisa dihindari beberapa kegiatan saat ini bisa dikombinasikan antara offline dan online dengan menerapkan kegiatan yang bisa dilakukan dengan daring (dalam jaringan / online). Misalnya ibu-ibu posyandu dapat mengisi kuesioner dulu melalui online untuk mengisi waktu kedatangan sebelum tiba di Posyandu. Dengan mengisi form online tersebut maka kegiatan berkerumun pada jam yang sama dapat dihindari dan terbagi dalam waktu yang tidak bersamaan. Selaku dosen Teknologi Informasi sudah selayaknya membagikan ilmu kepada masyarakat agar masyarakat juga mengetahui teknologi yang sederhana dan tepat guna. Oleh karena itu Pengabdian Masyarkat ini membahas tentang penggunaan Google Form untuk Ibu-ibu Posyandu Seruni dengan tujuan agar ibu-ibu posyandu juga dapat memanfaatkan google form ini untuk kegiatan yang bermanfaat. Kegiatan pengabdian masyarakat ini dilakukan secara daring dengan menggunakan aplikasi Zoom Meeting. Luaran yang dihasilkan dari pengabdian masyarakat berupa press release yang diterbitkan secara online dan jurnal pengabdian masyarakat.
\end{abstract}

Kata Kunci: pengabdian masyarakat, kuesioner, google form

\section{Abstract}

In a pandemic condition like today, many activities cannot be carried out normally by meeting and gathering which involve many people in an event. This can be a problem if you have to collect data for research purposes or other personal needs. Even though during the pandemic, activities for Posyandu mothers must also continue by implementing strict health protocols in order to keep the transmission of the corona virus. To reduce the inevitable gathering activities, some current activities can be combined between offline and online by implementing activities that can be done online (in network / online). For example, posyandu mothers can first fill out a questionnaire via online to fill in the arrival time before arriving at the Posyandu. By filling in the online form, crowd activities at the same time can be avoided and divided into different times. As an Information Technology lecturer, it is appropriate to share knowledge with the public so that people also know simple and effective technology. Therefore this Community Service discusses the use of Google Form for Posyandu Seruni mothers with the aim that posyandu mothers can also take advantage of this google form for useful activities. This community service activity is carried out online using the Zoom Meeting 
application. The output generated from community service is in the form of press releases published online and community service journals.

Keywords: community service, questionnaires, google form

\section{Pendahuluan}

Dalam rangka membantu program pemerintah untuk meningkatkan kesehatan masyarakat, khususnya dalam meningkatkan kesehatan bayi, balita, ibu hamil dan menyusui dilingkungan RW 01 Kel. Buaran Indah maka dibentuklah Posyandu Seruni dan pertama kali didirikan pada tahun 1983 oleh Ibu-Ibu Pegawai Komplek Kehakiman dan HAM yang sekarang masih Aktif.

\section{Letak Data Geografi}

Wilayah, Jl.Pengayoman Utara II RT03/ RW. 01, Komp.kehakiman dan HAM Kota Tangerang dengan luas Tanah $250 \mathrm{M}$, yang berbatasan dengan :

Sebelah Barat : RT. 04/01

Sebelah Utara : Mushola Nurul Fallah

Sebelah Selatan : Jalan Pengayoman Utara 5

Sebelah Timur : Rumah Warga Kehakima

\section{Visi dan Misi}

\section{Visi}

PKK menjadi penggerak kesejahtraan keluarga dan kesehatan

Misi

- Meningkatkan Pelayanan kesejahteraan Keluarga dengan Program Keluarga Berencana

- Memberikan Pelayanan Kesehatan kepada masyarakat khususnya di RW 01 Kel.Buaran Indah Kota Tangerang

Dalam kondisi pandemi seperti saat ini, banyak kegiatan yang tidak dapat dilakukan secara normal dengan bertemu dan berkumpul yang melibatkan banyak orang dalam sebuah acara. Hal ini dapat menjadi masalah jika harus melakukan pengumpulan data untuk keperluan penelitian maupun keperluan pribadi lainnya. Walaupun dimasa pandemi tetapi kegiatan untuk Ibu-ibu Posyandu juga harus tetap berjalan dengan menerapkan protokol kesehatan yang ketat demi menjaga penularan virus corona. Untuk mengurangi kegiatan berkumpul yang tidak bisa dihindari beberapa kegiatan saat ini bisa dikombinasikan antara offline dan online dengan menerapkan kegiatan yang bisa dilakukan dengan daring (dalam jaringan / online).

Peraturan pemerintah yang membatasi kegiatan masyarakat selama pandemi virus corona (Corona Virus Deseas) saat ini memberikan dampak sosial yang sangat besar bagi kehidupan masyarakat pada umumnya. Pemerintah memberlakukan Pembatasan Sosial Berskala Besar (PSBB) mempunyai tujuan agar penularan virus dapat dikendalikan dan dalam jangka panjang dapat dihilangkan sama sekali. (Junaidi, Yani, \& Wahyudin, 2021)

Sebagai referensi pengabdian yang telah dilakukan sebelumnya adalah, keakraban masyarakat dengan berbagai produk teknologi seperti Komputer, Tablet dan Smartphone, serta tersedianya koneksi internet yang semakin murah juga menjadi peluang untuk pemanfaatan teknologi informasi dan komunikasi dalam pelaksanaan sistem pendidikan. Salah satu software yang mudah diakses, gratis digunakan, sederhana dalam pengoperasiannya, dan 
cukup baik untuk dikembangkan sebagai alat evaluasi kinerja dosen pada proses pembelajaran adalah Google Form (H H Batubara, 2016)

Google Form atau yang disebut google formulir adalah alat yang berguna untuk merencanakan acara, mengirim survei, memberikan siswa atau orang lain kuis, atau mengumpulkan informasi yang mudah dengan cara yang efisien (Agustin, Suryono, \& Yuliandari, 2017).

Salah satu aplikasi yang dapat digunakan secara gratis untuk membantu dosen dan mahasiswa dalam membuat kuis dan survei online adalah Google Form, yaitu salah satu layanan Google Docs (Hamdan Husein Batubara, 2017).

Permasalahan penyelenggaraan acara-acara yang diselenggarakan oleh Posyandu Seruni baik rapat untuk pengambilan keputusan maupun survei-survei selama ini harus memberikan undangan atau form kuesioner yang diberikan dan diisi langsung oleh anggota maupun panitia penyelenggara. Selama kondisi pandemi covid hal ini menjadi masalah karena berbagai aturan berkerumun yang ditetapkan oleh pemerintah ataupun pemerintah daerah setempat. Oleh karena itu diperlukan pelatihan pembuatan dan penggunaan survey atau kuisioner online dengan google foorm agar dapat menjembatani kegiatan ini.

\section{Metode}

Metode pelaksanaan yang digunakan dalam menyelesaikan permasalahan, yaitu:

1. Tahap Persiapan

Tahap ini dilakukan untuk mengetahui permasalahan yang dihadapi oleh Ibu-ibu anggota Posyandu Seruni. Selanjutnya melakukan persiapan untuk pelatihan dengan membuat materi pelatihan/ workshop mengenai pembuatan survey secara online menggunakan google form.

2. Tahap Pelaksanaan

Pada tahap ini semua peserta pelatihan diberikan pemaparan dengan materi mengenai bagaimana cara membuat survey secara online menggunakan google form.

Kegiatan pelaksanaan pengabdian ini dilaksanakan pada :

Hari : Sabtu

Tanggal $\quad: 3$ April 2021

Waktu : $09.00-12.00$

Link zoom

https://zoom.us/j/92296237501?pwd=QUNnNVlMYWhSZzdpQmZ2RWVwcVdSQT09 Meeting ID: 92296237501 Passcode: d7kcp7

3. Tahap Monitoring dan Evaluasi

Pada tahap ini dilakukan dengan melakukan percobaan untuk peserta dengan cara semua peseeta pelatihan membuat survei secara online menganai kegiatan yang akan dilakukan

\section{Hasil dan Pembahasan}

Dari kegiatan pengabdian masyarakat yang berupa pelatihan pembuatan kuisioner atau survey secara online menggunakan google form, berikut hasil dan pembahasan: 


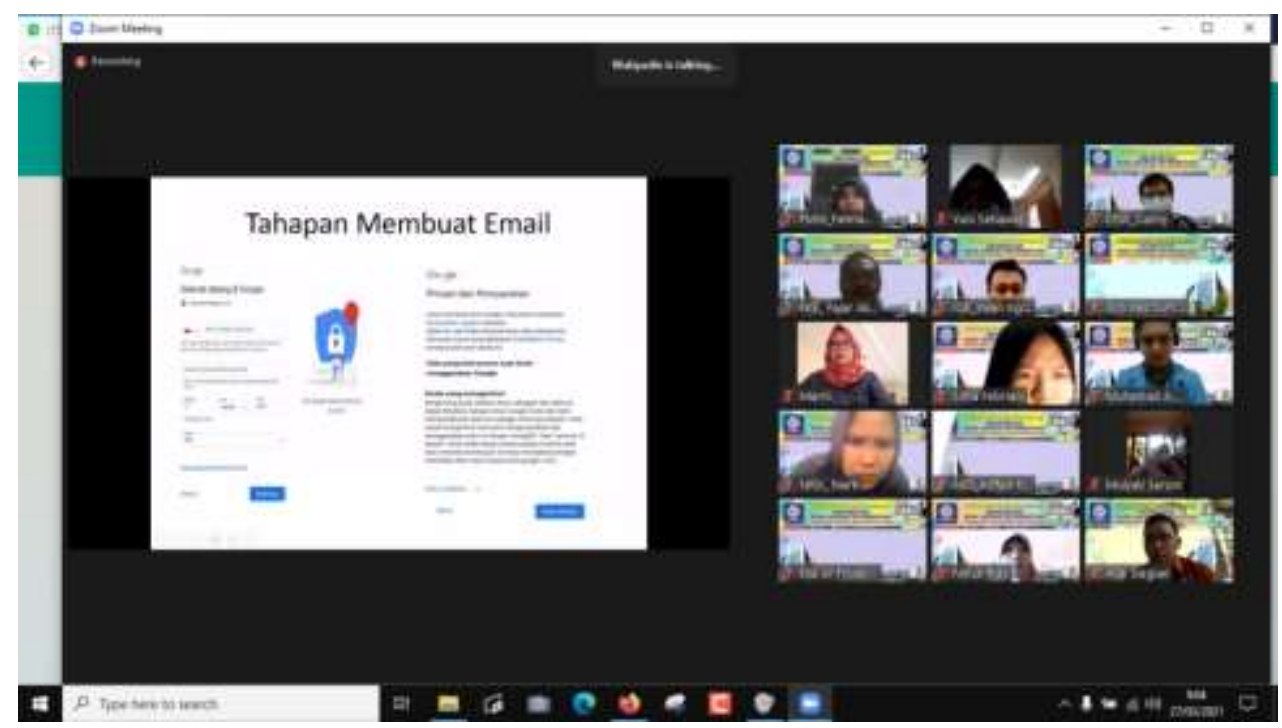

Gambar 1. Hasil Pelatihan Pengabdian Masyarakat Pembuatan kuesioner atau Survey Secara Online Menggunakan Google Form

Hasil dari kegiatan pengabdian masyarakat yang berupa pelatihan survey secara online menggunakan google form sebagai berikut:

a. Peserta kader posyandu dapat menambah pengetahuan di bidang teknologi informasi dan manfaatnya untuk kebutuhan berbagai kegiatan posyandu.

b. Peserta kader posyandu dapat memanfaatkan teknologi informasi dengan pemenfaatan google form untuk kegiatan atau aktivitas posyandu.

c. Peserta kader posyandu dapat melakukan pendataan secara online dengan baik tanpa harus berkumpul berkonsentrasi pada suatu tempat (meminimalkan kerumunan masa).

Tabel 1. Hasil Kuesioner PM Survey Secara Online Menggunakan Google Form Pada Posyandu Seruni

\begin{tabular}{llcccc}
\hline No & \multicolumn{1}{c}{ Pertanyaan } & Puas & \% & $\begin{array}{c}\text { Tidak } \\
\text { Puas }\end{array}$ & \% \\
\hline 1 & $\begin{array}{l}\text { Saya merasa puas dengan kegiatan } \\
\text { pengabdian } \\
\text { diselenggarakan Universitas Bina Sarana }\end{array}$ & 20 & 100 & 0 & 0 \\
& $\begin{array}{l}\text { Informatika } \\
\text { Kegiatan pengabdian masyarakat yang } \\
\text { disampaikan bermanfaat untuk menambah } \\
\text { wawasan, pengetahuan, keterampilan dan } \\
\text { keahlian peserta }\end{array}$ & & & & \\
\end{tabular}

\section{Kesimpulan}

Pelaksanaan kegiatan masyarakat yang dilakukan pada kader Posyandu Seruni berupa pelatihan Survey online menggunakan Google Form ini sangat bermanfaat bagi kader dalam melakukan berbagai pendataan dengan cepat dan tepat tanpa harus berkumpul sehingga dapat meminimalkan dan menghindari konsentrasi masa dalam situasi pandemi.

\section{Daftar Pustaka}

Agustin, A., Suryono, H., \& Yuliandari, E. (2017). Teknik Penilaian Diri Berbasis Google 
Form pada Mata Pelajaran Pendidikan Pancasila dan Kewarganegaraan. PKn Progresif, 12(1), 482-491.

Batubara, H. H. (2016). Penggunaan Google Form Sebagai Alat Penilaian Kinerja Dosen Di Prodi Pgmi Uniska Muhammad Arsyad Al Banjari. AL-BIDAYAH: Jurnal Pendidikan Dasar Islam, 8 (1), 39--50. AL-BIDAYAH: Jurnal Pendidikan Dasar Islam, 8(1), 39-50.

Batubara, H. H. (2017). Workshop Penggunaan Google Form Sebagai Media Evaluasi Pembelajaran Pada Dosen-Dosen Fakultas Studi Islam. Jurnal Pengabdian Al-Ikhlas Universitas Islam Kalimantan Muhammad Arsyad Al Banjary, 2(1), 39-44.

Junaidi, A., Yani, A., \& Wahyudin. (2021). Sosialisasi Adaptasi Kebiasaan Baru di Masa Pandemi Covid-19 Untuk Ibu-Ibu PKK Kelurahan Gembor, Tangerang. Abditeknika Jurnal Pengabdian Masyarakat, 1(1), 8-12.

Warjiyono, W., Suryanti, E., Rousyati, R., Fatmawati, F., Tazali, I., Lisnawati, L., \& Rosihyana, R. (2021). Pelatihan Aplikasi Perkantoran Untuk Meningkatan Kualitas SDM Perangkat Desa Karangmangu. Jurnal Abdimas BSI: Jurnal Pengabdian Kepada Masyarakat, 4(1), 156-163. 